source of "hashish" ; and the plant had grown from the refuse of a parrot's cage containing remains of a mixture from a chance packet of bird-seed. A point of insurance was decided by the relative inflam. mability of teff grass and ordinary hay. Questions of adulteration in manufactured chicory, inquiries about possible new sources of iodine, about diseases of bulbs, the qualities of timber for various specific purposes, the control of weeds, the identification of consignments of unrecognized materials, indicate the variety of information which is expected of a museum botanist.

\section{Textile Studies at Leeds}

REPORTS on the work of the session 1939-40 in the Departments of Textile Industries and of Colour Chemistry and Dyeing at the University of Leeds show that, although the number of students, particularly of those from overseas, has suffered to some extent and the time-table has had to undergo considerable alteration to meet the special conditions arising out of the War, the work of both Departments has been actively carried on and an impressive list of successes in the examinations of the University and of the City and Guilds of London Institute has been achieved. The degree of Ph.D. was conferred upon three students, one gained the M.Sc. degree and sixteen others graduated with honours. Twelve diplomas were awarded, while no fewer than forty-seven students obtained first class passes in the examinations of the City and Guilds of London Institute, several of them gaining prizes and silver medals. Facilities for work by the students in factories during the vacation, which forms a valuable and highly appreciated part of the training, have of necessity been somewhat restricted though not altogether suspended. In addition to the normal work of the research laboratories, much of which is carried out in co-operation with various firms in different parts of Great Britain, much attention is being devoted to problems of immediate national importance. Research activity has increased in intensity, not merely on account of the War, but also because of the appreciation shown by the industry in their results. A long list of recent publications in scientific journals is appended.

\section{Forest Research Programme at Dehra Dun}

THE triennial programme of work, 1940-42, of the Forest Research Institute, Dehra Dun, India (New Delhi : Government of India Press, 1940) gives evidence of the great progress made in this respect in India during the last three decades. When the Institute was inaugurated in 1906-7, the five branches still in force were decided upon, namely : sylvicultural, botanical, entomological, utilization and chemical. Some progressed more rapidly than others, notably utilization, as a result of the War of 1914-18 and the demands then made upon it. The present triennial programme shows, however, that advances in sound forest research have since made uniform progress in all the branches. The brochure is inevitably somewhat technical in many of the inquiries and research being undertaken, but in the sylvicultural branch investigations in various provinces are being carried on into that important subject in tropical forestry 'grazing combined with forestry'; also into erosion and soil-covering and its effects. The utilization branch has been for long subdivided into wood technology, timber testing, seasoning, wood preservation, paper pulp and wood workshop. Perhaps one of the surprising things about the Institute is that the minor forest products section, which is once again in 'cold storage', as it is expressed, owing to want of staff, has never received the serious attention which it so obviously seemed to demand. It would have been thought that from very early years in the functioning of the Institute, the Department and Government would have realized the enormous possibilities of research into the very large number of minor products of the Indian forests; lac and resin have already proved the value of experimental research work. It is difficult to understand this neglect.

\section{Riveted Joints and Welded Joints}

THE quarterly journal Electric Welding, issued by the Quasi-Arc Company, Ltd., Bilston, Staffs., is being discontinued. Advances which may occur in welded construction or technique will be published by distribution of technical circulars or by articles in technical or trade journals. The last issue of the journal (October) contains a paper by Prof. B. P. Haigh entitled "Riveted. Joints and Welded Joints", who points out that riveted joints can be relied on to meet all ordinary requirements, provided that the working drawings of the structure provide the necessary scantlings. So firmly established is this faith in riveted joints that almost any failure in a riveted structure is attributed, if not to accident, then to faulty design of the structure as a whole. A riveted structure, if neglected, may be expected eventually to deteriorate by rusting. Water percolates between the plates and forms rust, forcing the plates apart between the rivets. The rivets become tighter for a time but eventually loosen or crack, and the structure falls asunder.

Welded structures may be expected to last longer in such circumstances because overlapping plates or rolled sections can be and commonly are very efficient from the mechanical point of view ; thus channel sections welded back to back and welded all round the overlap, are so strongly joined that the rolled sections yield before the joints. The use of galvanized plates is not recommended either for riveting or welding, where full strength is required, particularly in vibration. At the high temperatures required for either riveting or welding, zinc is liable to penetrate between the grains in the steel, particularly when the metal is under tension, with the result that rivets and welds are then liable to crack in a brittle manner. When welds are made between galvanized plates of fair thickness, it is expedient to grind off the layer of zine from the surfaces that will carry the fillets ; but grinding is more difficult for riveted joints and is probably impracticable. 